\title{
AN INTRODUCTION TO DNA-RECOMBINANT TECHNOLOGY AND THEIR APPLICATION IN HUMAN THERAPUTICS
}

\author{
Maurya Avinash *, Sharma Pramod Kumar, Singh Jasbeer, Malviya Rishabh, \\ Department of Pharmacy, School of Medical and Allied Sciences, Galgotias University, Greater Noida, U.P., India
}

\begin{abstract}
:
Recombinant DNA-technology is one further step of genetic engineering, which enable us to mass production of safe, pure and effective biological products. Recombinant DNA is artificially created from two or more DNA incorporated into a single molecule. Genetic engineering, recombinant DNA technology, genetic modification/manipulation and gene splicing are terms that are applied to the direct manipulation of an organism's gene. Recombinant DNA are used to produce biochemical's such as hormones of therapeutic interest, haemopoietic growth factors, blood coagulation products, thrombolytic agents, anticoagulants, interferon, interleukins and therapeutic enzymes. The biochemically derived biochemical is large extracellular proteins for use in either chronic replacement therapies or for the treatment of life threatening indications. This article focuses on basic concepts behind the recombinant DNA technique and current trend in recombinant DNA technology.
\end{abstract}

Key Words: Recombinant DNA-technology, genetic engineering, thrombolytic agents, anticoagulants, interferon, interleukins.

\section{INTRODUCTION:}

In the pharmaceutical industries, recombinant DNA technology has brought about a rapid growth and advancement in therapeutics available for human use ${ }^{1}$. This article focuses on recombinant DNA-technology and their application in modern therapeutics. Modern researches are ongoing to investigate the function of a particular gene. A gene is responsible for production of particular type of protein which, in turns, plays an important role in determination of final phenotype of an organism. Thus by r-DNA technology, we can reproduce desired biological products ${ }^{2}$. Recombinant DNA is a DNA which is made by splicing of a foreign DNA, and rejoining fragments into a small replicating molecule. DNA from two or more sources are joint in to a single $r$ DNA. DNA from both sources are treated with restriction endonuclease, which cut on same site on both DNA molecules, 5'GGATCC3', 3'CCTAGG5'. Overhanging pieces at the ends of single stranded DNA are called "sticky ends", because they may base pair with any DNA molecule containing the complementary sticky ends. In above case both pairs with other in mixture since they are complementary.

DNA ligase covalently joint two pieces of DNA to form r-DNA molecule. Clones of r-DNA are synthesizes, in vitro, by the process called polymerase chain reaction (PCR). Recombinant DNA then produced desired biological product. In vivo cloning of $r$ - DNA can be carried out by unicellular microbes like $E$. coli, yeast and mammalian cells in tissue culture. In each case r-DNA must be introduced in cell for replication and expression.
DNA vector is used for r-DNA transfer in to organism ${ }_{5}^{3,4}$, 5 .

\section{Vectors}

Bacterial plasmid is the most commonly used vector. Plasmids used in genetic engineering are under control; their replication is totally independent of chromosomal replication. These plasmids may be present in copies of 10-700 per cell. The most popular plasmid is pUC18. Bacterial plasmids cannot accept DNA strands larger than 5000 base pairs; hence they are restricted to cloning DNA $\leq 5000$ base pairs.

Many viruses also serve as vector for bacterial and mammalian cell. Bacteriophage lambda virus can incorporate up to 15-16 kilobases of DNA segment. A central one-third of its genome is normally not required for infection and therefore can be replaced by foreign $\mathrm{DNA}^{6}$.

*for correspondence: Department of Pharmacy, School of Medical \& Allied Sciences, Galgotias University, Plot No.2, Sector 17-A, Yamuna Expressway, Greater Noida, U.P., India Mobile no: +918860146248

Email: avinashmaurya88@gmail.com 


\section{MOLECULE A}

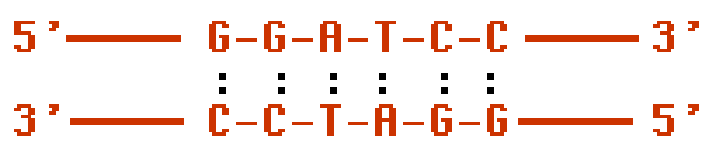

\section{MOLECULE B}

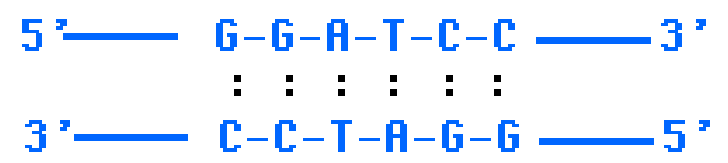

\section{Digest each with same restriction} endonuclease, BamHI

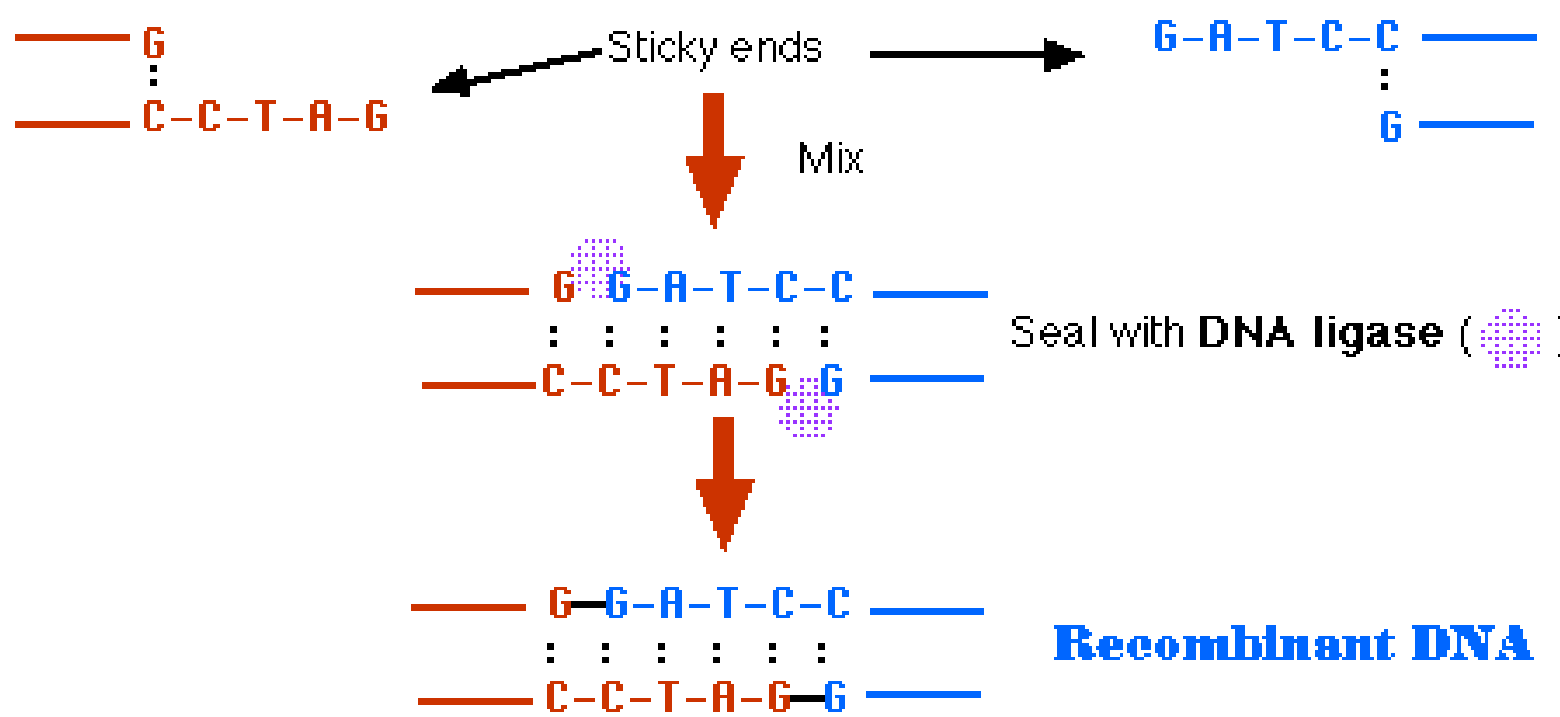

Figure 1: Making recombinant DNA(r-DNA): An overview

\section{RECOMBINANT DNA TECHNOLOGY:}

METHOD $^{7,8,9,10}$ :

\section{ISOLATION OF GENE:}

The desired gene responsible for production of particular biological product is isolated from cell. The procedure for isolation of DNA depends on the nature of donor. Two enzymes are very important in DNA isolation and rDNA synthesis; restriction endonuclease and DNA ligase. Restriction endonuclease recognizes a specific nucleotide sequence on DNA molecule, called restriction site and cleave DNA at this site. DNA ligase is responsible for joining two pieces of DNA by forming phosphodiester bonds.

\section{PREPARATION OF RECOMBINANT DNA:}

In 1973, two scientists named Boyer and Cohen developed a way to transfer DNA from one organism cell into DNA of bacteria. This provides roadmap for recombinant DNA technology ${ }^{4}$. The circular plasmid vector from bacterial cell is removed, and Special proteins are used to cut the plasmid ring to open its ring.

\section{INCERTION OF DNA INTO PLASMID:}

The desired DNA from host is inserted into open vector plasmid DNA ring. DNA ligase is required to seal the gaps. These enzymes covalently bonded two strands and generate a circular DNA molecule. The most commonly used DNA ligase, in the labs, is derived from bacteriophase $\mathrm{T}_{4}$.

\section{INCERTION OF PLASMID BACK INTO BACTERIAL CELL:}

Circular DNA molecule with desired host gene is transferred into bacterial cell. As plasmid is natural part of bacterial cell, it is auto accepted by bacteria. Now the reformed bacterial cell has host gene from different organism, this is called recombinant bacterial cell, and used for production of desired biological products.

\section{PLASMID MULTIPLICATION ${ }^{11}$ :}

The inserted plasmid i.e. recombinant plasmid, can multiply in bacterial cell make several copies of wanted gene. Now these copies can transfer to many bacterial cells. Also, when bacterial cell reproduce by dividing, the recombinant plasmid reproduced in newly generated cell. Now, these cells are used for mass production of desired protein. The protein that is produced by r-DNA technology is purified and used for medicinal and industrial purpose. 


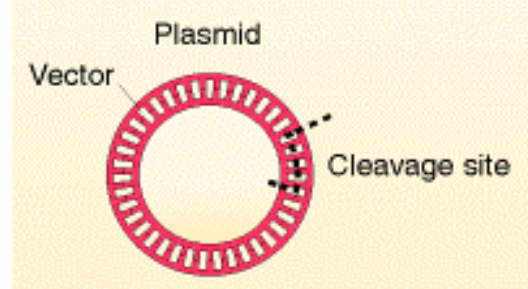

(a)

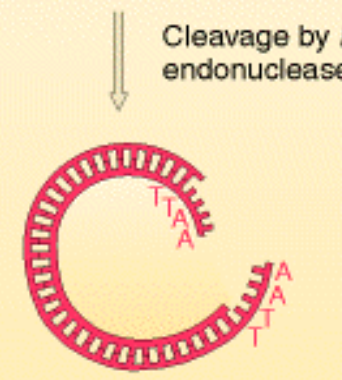

by ECORI Eco

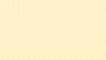
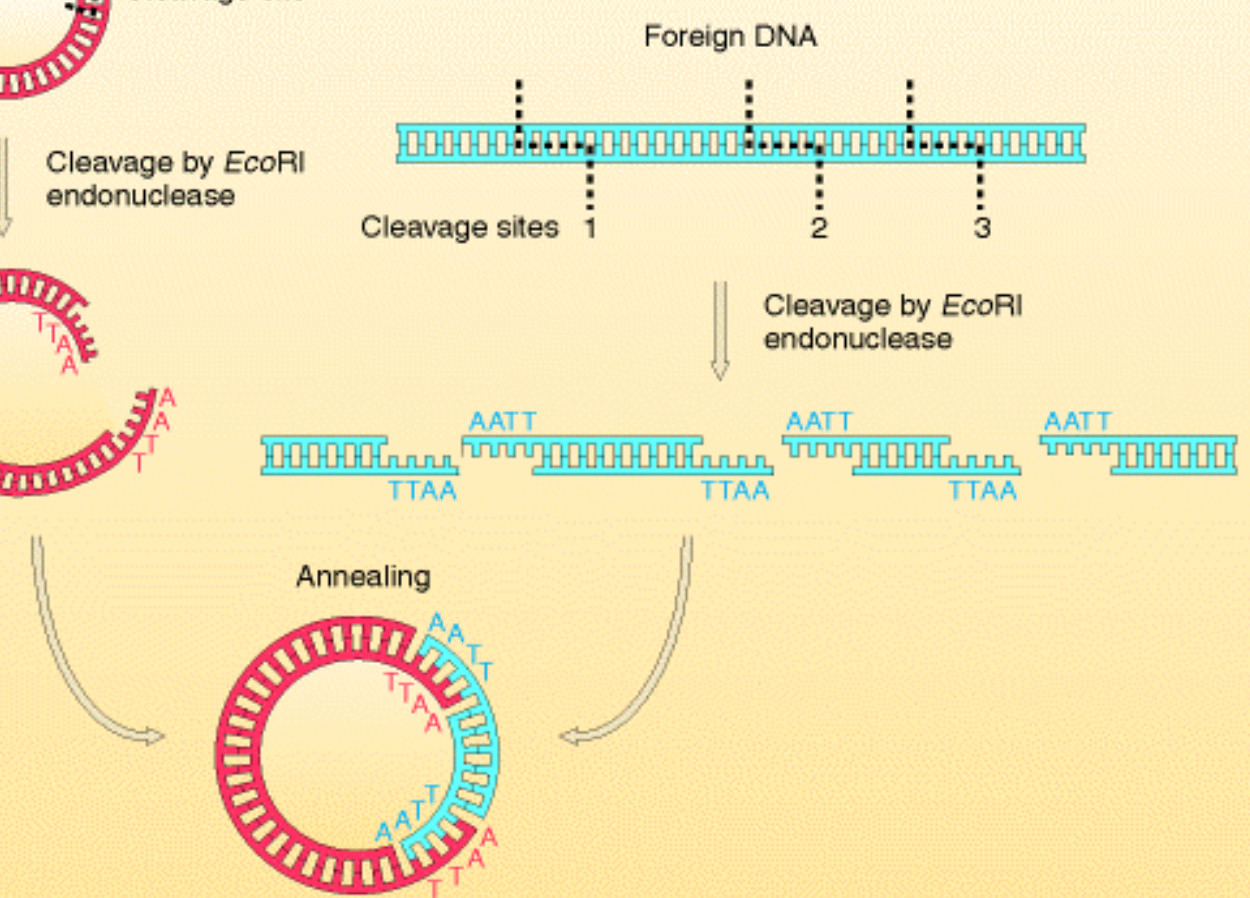

(b)

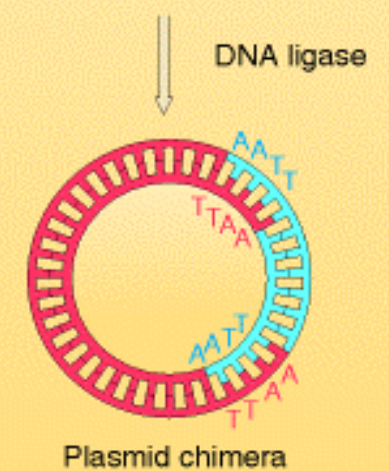

Figure 2: Method for generating a chimeric DNA plasmid containing genes derived from foreign DNA. (From S. N. Cohen, "The Manipulation of Genes." Copyright $(\mathcal{O} 1975$ by Scientific American, Inc. All rights reserved).

\section{APPLICATION OF RECOMBINANT DNA TECHNOLOGY IN HUMAN THERAPEUTICS:}

\section{HORMONES:}

Diabetes mellitus characterized by hyperglycemia is most common disease worldwide. Hyperglycemia is a result of defects in insulin secretion, action or both. Disease can be treated by administration of recombinant insulin produced by $\quad S$. cerevisae or E. coli, which is structurally similar as human insulin. It provides rapid absorption when compared to regular human insulin 13 . It provides long peak less action with better effects during down hours ${ }^{14}$.

Insulin glargine is a, long acting insulin structurally differs from human insulin at 21 position, where glycine is replaced by aspargine ${ }^{15}$.
Insulin lispro, produced by E. coli, differ from human insulin by transposition of proline and lysine at 28 and 29 positions in beta chain ${ }^{16}$.

Insulin glulicin is rapid parenteral hypoglycemic produced by $\mathrm{E}$. coli, differ from human insulin by replacing aspargin by lysine at B3and lysine at B26 is replaced by glutamic acid ${ }^{17}$.

Recombinant follicle stimulating hormone (rFSH) and recombinant human chorionicgonadotropin (rhuCG) are produced by $\mathrm{CHO}$ cells, use to treat the infertility in humans $1^{8,19}$.

Somatotropin produced by E. coli is a recombinant growth hormone used to treat growth hormone deficiency. It differ from human growth hormone by containing additional methionin at N-terminus of molecule ${ }^{20}$. 
Table 1: Some r-DNA products approved by FDA for human application ${ }^{12}$

\begin{tabular}{|c|c|c|c|}
\hline $\begin{array}{l}\text { Therapeutic } \\
\text { category }\end{array}$ & Product & Expression host & Abbreviated indication \\
\hline \multirow[t]{2}{*}{$\begin{array}{l}\text { Hormone of } \\
\text { therapeutic interest }\end{array}$} & $\begin{array}{l}\text { Human insulin } \\
\text { Insulin aspart } \\
\text { Insulin glargine } \\
\text { Insulin lispro } \\
\text { Insulin glulisine } \\
\text { Human } \\
\text { choriogonadotropin }\end{array}$ & $\begin{array}{l}\text { E. colil } \quad S . \\
\text { cerevisiae } \\
\text { S. cerevisiae } \\
\text { E. coli } \\
\text { E.coli } \\
\text { E. coli } \\
\text { CHO cell }\end{array}$ & $\begin{array}{l}\text { Treatment of diabetes } \\
\text { Treatment of diabetes } \\
\text { Treatment of diabetes } \\
\text { Treatment of diabetes } \\
\text { Treatment of diabetes } \\
\text { Treatment of women undergoing superovulation } \\
\text { prior to assisted reproductive techniques such as } \\
\text { in vitro fertilization }\end{array}$ \\
\hline & $\begin{array}{l}\text { Follicle-stimulating } \\
\text { hormone } \\
\text { Luteinizing hormone } \\
\text { Somatotrophin }\end{array}$ & $\begin{array}{l}\text { CHO cell } \\
\text { CHO cell } \\
\text { E. coli }\end{array}$ & $\begin{array}{l}\text { Treatment of infertility } \\
\text { Induction of ovulation } \\
\text { Treatment of deficiency of growth failure }\end{array}$ \\
\hline \multirow[t]{3}{*}{$\begin{array}{l}\text { Haemopoietic } \\
\text { growth factors }\end{array}$} & $\begin{array}{l}\text { Erythropoietin alpha } \\
\text { Erythropoietin beta } \\
\text { Erythropoietin omega }\end{array}$ & $\begin{array}{l}\text { CHO cell } \\
\text { CHO cell } \\
\text { BHK cell }\end{array}$ & $\begin{array}{l}\text { Treatment of anemia associated with renal } \\
\text { failure, HIV infection, cancer. } \\
\text { Treatment of anemia associated with renal } \\
\text { failure. } \\
\text { Treatment of anemia associated with renal } \\
\text { failure, cancer. }\end{array}$ \\
\hline & Darbepoetin & CHO cell & $\begin{array}{l}\text { Treatment of anemia associated with renal } \\
\text { failure, cancer. }\end{array}$ \\
\hline & Surgramostim & S. cerevisiae & $\begin{array}{l}\text { Reduction in duration of neutropenia and } \\
\text { incidence of febrile neutropenia in patients } \\
\text { treated with cytotoxic chemotherapy for } \\
\text { malignancy } \\
\text { Treatment of neutrophil recovery }\end{array}$ \\
\hline $\begin{array}{l}\text { Therapeutic } \\
\text { enzymes }\end{array}$ & $\begin{array}{l}\text { Dorsase alpha } \\
\text { Glucocerebrosidase }\end{array}$ & $\begin{array}{l}\text { CHO cells } \\
\text { CHO cells }\end{array}$ & $\begin{array}{l}\text { Cystic fibrosis } \\
\text { Replacement therapy in patients with Gaucher } \\
\text { disease }\end{array}$ \\
\hline Human interleukins & $\begin{array}{l}\text { Interleukin-2 } \\
\text { Interleukin-11 }\end{array}$ & $\begin{array}{l}\text { E. coli } \\
\text { E. coli }\end{array}$ & $\begin{array}{l}\text { Renal cell carcinoma } \\
\text { Treatment of thrombocytopenia }\end{array}$ \\
\hline Anticoagulants & $\begin{array}{l}\text { Lepirudin } \\
\text { Desirudin }\end{array}$ & $\begin{array}{l}\text { S. cerevisiae } \\
\text { S. cerevisiae }\end{array}$ & $\begin{array}{l}\text { Anticoagulation therapy for heparin associated } \\
\text { thrombocytopenia } \\
\text { Prevention of venous thrombosis }\end{array}$ \\
\hline Human interferon & $\begin{array}{l}\text { Interferon alpha- } 2 \mathrm{~b} \\
\text { Interferon beta- } 1 \mathrm{~b} \\
\text { Interferon gamma }\end{array}$ & $\begin{array}{l}\text { E. coli } \\
\text { E. coli } \\
\text { E. coli }\end{array}$ & $\begin{array}{l}\text { Treatment of hairy cell leukaemia, chronic } \\
\text { hepatitis B and C, AIDS, cancer } \\
\text { Treatment of multiple sclerosis } \\
\text { Chronic granulomatous disease }\end{array}$ \\
\hline $\begin{array}{l}\text { Human blood } \\
\text { coagulation factors }\end{array}$ & $\begin{array}{l}\text { Factor VIII } \\
\text { Factor IX } \\
\text { Factor VII A }\end{array}$ & $\begin{array}{l}\text { CHO cells } \\
\text { CHO cells } \\
\text { BHK cell }\end{array}$ & $\begin{array}{l}\text { Treatment of haemophilia A } \\
\text { Treatment of haemophilia B } \\
\text { Treatment of haemophilia A and B }\end{array}$ \\
\hline $\begin{array}{l}\text { Thrombolytic } \\
\text { agents }\end{array}$ & $\begin{array}{l}\text { Alteplase } \\
\text { Reteplase } \\
\text { Tenecteplase } \\
\text { Saruplase }\end{array}$ & $\begin{array}{l}\text { CHO cells } \\
\text { E. coli } \\
\text { CHO cells } \\
\text { E. coli }\end{array}$ & $\begin{array}{l}\text { Treatment of acute myocardial infarction } \\
\text { Treatment of acute myocardial infarction } \\
\text { Treatment of acute myocardial infarction } \\
\text { Thrombolytic therapy for acute myocardial } \\
\text { infarction }\end{array}$ \\
\hline
\end{tabular}

\section{HAEMOPOIETIC GROWTH FACTORS:}

Recombinant human erythropoietin (rhuEPO) is use to treat HIV infection, cancer renal failure and surgery. Epoetin alpha, epoetin beta and epoetin omega are three rhuEPO available for human application ${ }^{21}$.
Darbepoetin alfa has been developed for the treatment of anemia $^{22}$.

\section{BLOOD COAGULATION FACTOR:}

Deficiency of human coagulation factor VIII causes hemophilia $\mathrm{A}$, the most common inherited bleeding 
disorder. Recombinant human factor VIII, produced in CHO cell provides temporary control on bleeding ${ }^{23,24}$.

\section{THROMBOLYTIC AGENTS:}

Tissue plasminogen activator (TPA) is used to dissolve thrombus in blood vessels. Alteplase a recombinant tissue plasminogen activator (rTPA) stimulates thrombolysis by converting plasminogen to plasmin. Now, this is treatment of choice for acute myocardial infarction (AMI) ${ }^{25}$.

\section{ANTICOAGULANTS:}

Lipirudin, a recombinant derivative of leech anticoagulant hirudin, is used for treatment of heparin induced thrombocytopenia, produced by using yeast cells ${ }^{26}$.

\section{HUMAN INTERFERON:}

The three recombinant human interferons (rhuIFN) are alpha, beta and gamma. Recombinant human interferon are indicated for hairy cell leukemia and chronic granulomatous disease ${ }^{27,28}$.

\section{HUMAN INTERLEUKINS:}

The recombinant human interleukins (rhuIL)-2 produced in E. coli, is indicated for treatment of renal cell carcinoma and melanoma ${ }^{29,30}$.

\section{THERAPUTIC ENZYMES:}

\section{REFERENCE:}

1. Reichert, J. M. and Paquett, C., Therapeutic recombinan proteins: Trends in US approvals 1982-2002. Curr. Opin. Mol Ther., 2003,5, pp 139-147.

2. Watson, J.D., Gilman, M., Witkowski, J., Zoller, M. Recombinant DNA, Scientific American Books, New York, 1992; pp 213.

3. Charce, R.E. and Frank, B.H. Research, Production and Safety of Biosynthetic Human Insulin, 1993; pp 543,566.

4. Court, Dr J. Modern Living with Diabetes, Diabetes Australia, Melbourne, 1990;pp 211.

5. Cheon, K. M., Byun, H. K., Yang, K. M., Song, I. O., Choi, K. H. and Yoo, K. J., Efficacy of recombinant human follicle stimulating hormone in improving oocyte quality in assisted reproductive techniques. J. Reprod. Med., 2004, 49, pp733738.

6. http/www. Microrao.com.

7. Doran, P.M. Directory in Modern Biotechnology, Hawker Brownlow Education, 1990; pp534-537.

8. Encyclopedia of Science Technology, McGraw-Hill Book Company, 1987;pp 642.

9. Recombinant DNA, Grolier Electronic Publishing.1992; pp76.

10. Kammermayor K. and Clark, V. L. Genetic Engineering Fundamentals, An introduction to Principles \& Applications, Marcel Decker Inc.1989;pp 312.

11. Morrow, J.F., Cohen, S.N., Chang, A.C.Y., Boyer, H.W., Goodman, H.M., Helling, R.B. (1974) Replication and transcription of eukaryotic DNA in Escherichia coli. Proceedings of the National Academy of Science USA 71:pp1743-1747.

12. Bhopale, G. M., and Nanda R. K., Recombinant DNA expression for human therapeutic use; Current science, vol. 89, no. 4,August 2005,pp5-6.

13. Mc Evoy, G. K., AHFS drug information, American Society of Health System Pharmacists, Bethesda, 2001, pp. 29772998.

14. Chapman, T. M., Noble, S. and Goa, K. L., Insulin aspart: A review of its use in the management of type 1 and 2 diabetes mellitus. Drugs, 2002, 62,pp 1945-1981.
Deficiency of glucocerebrocidase enzyme causes Gauchers' disease. Recombinant glucocerebrocidase is indicated for treatment of Gauchers' disease ${ }^{31}$.

\section{CONCLUSION:}

Recombinant DNA technology has indeed made tremendous breakthrough in the discovery of advance therapeutics. Besides the products approved by FDA for human use, several products are undergoing clinical trials. Products are developed in the field of haematology, endocrinology and oncology. The development of this new technology has resulted into production of large amount of biochemically defined proteins of medical significance and created an enormous potential for pharmaceutical industries. The biochemically derived therapeutics is large extracellular proteins for use in either chronic replacement therapies or for the treatment of life threatening indications. Recombinant DNA technology has also an important role in forensic science in identification of criminals, DNA profiling. Use of recombinant DNA, important genes, especially mammalian genes, could be amplified and cloned in foreign organisms. This provided a different approach to complex biological problem-solving. This cell-based, protein manufacturing technologies offer many advantages, producing recombinant pharmaceutically important proteins which are safe and effective for human application.
15. Dunn, C. J., Plosker, G. L., Keating, G. M., Mckeage, K. and Scott, L. J., Insulin glargine: An updated review of its use in the management of diabetes mellitus. Drugs, 2003, 63, pp1743-1478

16. Dunn, J. and Plosker, G. L., Insulin lispro: A pharmaco economic review of its use in diabetes mellitus. Pharmacoeconomics, 2002, 20,pp 989-1025.

17. Vazquez-Carrera and Silvestre, J. S., Insulin analogues in the management of diabetes. Methods Find. Exp. Clin. Pharmacol., 2004, 26, pp445-461.

18. Hugues, J. N., Recombinant human follicle-stimulating hormone: A scientific step to clinical improvement. Reprod. Biomed. Online, 2001, 2,pp 54-64.

19. Cheon, K. M., Byun, H. K., Yang, K. M., Song, I. O., Choi, K. H. and Yoo, K. J., Efficacy of recombinant human follicle stimulating hormone in improving oocyte quality in assisted reproductive techniques. J. Report. Med., 2004, 49, pp733738.

20. Mehta, A. and Hindmarsh, P. C., The use of somatropin (recombinant growth hormone) in children of short stature paediatr. Drugs, 2002, 4,pp 37-47.

21. Markham, A. and Bryson, H. M., Epoetin alfa, a review of its pharmacodynamics and pharmacokinetic properties and therapeutic use in non renal application. Drugs, 1995, 49, pp232-254.

22. Joy, M. S., Darbepoetin alfa: A novel erythropoiesis stimulating protein. Ann. Pharmacother., 2002, 36, pp11831192.

23. Bhopale, G. M. and Nanda, R. K., Blood coagulation factor VIII: An overview. J. Biosci., 2003, 23,pp 783-789.

24. Berntrop, P. E. et al., Modern treatment of hemophilia. Bull. W.H.O., 1995, 73,pp 691-701.

25. Doggrell, S. A., Alteplase: Descendancy in myocardial infarction, ascendancy in stroke. Expert Opin. Investing. Drugs, 2001, pp 2013-2029.

26. Greinacher, A., Lepirudin: A bivalent direct thrombin inhibitor for anticoagulation therapy. Expert Rev. Cardiovasc. Ther., 2004, 2,pp 339-357. 
27. Barrows, L. R., Antineoplastic and immunoactive drugs. In The Science and Practice and Pharmacy (ed. Gennaro, A. R.), Remington, 2000, pp. 1495.

28. Bolinger, A. M. and Taeubel, M. A., Recombinant interferon gamma for treatment of chronic granulomatous disease and other disorders. Clin. Pharm., 1992, 11, pp834-850.

29. Jeal, W. and Goa, K., Aldesleukin (recombinant interleukin-2): A review of its pharmacological properties, clinical efficacy and tolerability in patients with renal cell carcinoma. Biodrugs, 1997, 7,pp 285-317.

30. Noble, S. and Goad, K., Aldesleukin (recombinant interleukin2): A review of its pharmacological properties, clinical efficacy and tolerability in patients with metastatic melanoma. Biodrugs, 1997, 7, pp394-422.

31. Whittington, R. and Goad, K. L., Alglucerasae: A review of its therapeutic use in Gaucher's disease. Drugs, 1992, 44, pp7293. 